\title{
The Exogenous Shock of COVID-19: An Evidence from Financial Sector of an Emerging Economy
}

\author{
Md. Enamul Hasan (Corresponding author) \\ Lecturer, Army Institute of Business Administration \\ Savar Cantonment, Dhaka-1344, Bangladesh \\ E-mail: enamulhasan@aibasavar.edu.bd
}

\begin{abstract}
Asma Ahmed
Assistant Professor, Department of Finance and Banking, Jahangirnagar University

Savar, Dhaka-1342, Bangladesh

E-mail: asma.ahmed@juniv.edu
\end{abstract}

\begin{abstract}
Rowshonara Akter Akhi
Lecturer, Department of Finance and Banking, Jahangirnagar University

Savar, Dhaka-1342, Bangladesh

E-mail: rowshonakhi@juniv.edu
\end{abstract}

Received: July 9, 2021 Accepted: November 5, 2021 Published: November 30, 2021

doi:10.5296/bmh.v9i2.19288 URL: https://doi.org/10.5296/bmh.v9i2.19288

\begin{abstract}
This paper analyses the effect of COVID-19 on the financial sector of Bangladesh. Particularly, it explores how this pandemic has affected this industry, considering firms' past (pre-pandemic) financial characteristics. Employing the Generalised Estimation Equations (GEE) method with 1050 firm-year observations, which includes listed Banks, Financial Institutions, and Insurance companies' data obtained from annual reports, datastream, and WHO, we found that firms with the larger size, more leverage, liquidity, and higher ROA is more resilient to stock return declines reacting to this pandemic. This study should be of interest to investors and regulators as it provides new evidence related to an industry's pandemic and stock market response based on their prior financial characteristics. Besides, it will contribute to the extant literature of COVID-19 and the firm's stock return from an
\end{abstract}


emerging economy perspective.

Keywords: COVID-19, stock returns, financial sector, Bangladesh 


\section{Introduction}

The outbreak of COVID-19 has revealed significant uncertainty of globalisation and the intensity of the global spillover effect between countries (Zaremba et al., 2021). Economic activities, business functions, and people's lives have been affected severely by the concurrent COVID-19 pandemic worldwide (Kocaarslan \& Soytas, 2021). As a result, most banks have faced a considerable credit loss risk in several quarters due to the sudden shutdown of global activities during the pandemic (Blank et al., 2020). However, governments in every country have taken proper initiatives to lessen the adverse effects of this ongoing pandemic on the economic and financial scopes. However, this is inescapable to observe massive and long-lasting impacts on financial sectors due to this uncertain economic environment caused by the COVID-19 pandemic (Kocaarslan \& Soytas, 2021).

Major stock market indexes have faced a market shock by losing most of the stock prices; in the United States, stock prices for most industries recovered about two-thirds of their value lost within six months of the initial collapse (Didier et al., 2021). In general, the demand-side reduction may lead to an economic meltdown for long after the epidemic has ended up, thus falling the asset prices (Andersen et al., 2020). In Bangladesh, the financial sectors lost their market value by $8.96 \%$ at the declaration month of the COVID-19 pandemic, while banks, non-bank financial institutions and insurance industries lost their market price by $6.33 \%$, $13.98 \%$ and $14.22 \%$, respectively, in March 2020. The financial sectors have recovered this significant loss caused by the pandemic within five months after the month of declaration. That is why it is necessary to resolve the problem of the financial sector during any typical economic crisis by identifying and isolating the part of this sector that is in trouble, i.e., financial distress, supporting firms to maintain their organisational capital, and also initiating the firm hibernation for avoiding the economic costs of breaking firms (Didier et al., 2021).

In contrast, the positive side of COVID-19 towards Sharia economy is that there is a vibrant encouragement of the halal and tayyib lifestyle, as well as the increase of religious awareness, have prompted the business opportunities in the implementation of the Islamic banking and Sharia economic integration models (Hasan, 2020). On the other hand, during this ongoing pandemic, there is a rise in unemployment because of the workplace's termination, as the borrower households who highly rely on bank credit to fund consumption are the sufferers of losing their jobs in this recession (Faria-e-Castro, 2021). Therefore, this sudden rise in unemployment caused by the COVID-19 pandemic has an adverse effect on the financial sector literally.

Consequently, the financial sector is very crucial for both the stock market and the national economy. For that reason, this paper aims to discover the factors affecting the profitability of financial firms due to this concurrent COVID-19 pandemic. In particular, we want to determine if the impact of COVID-19 on the stock returns of Financial companies changes depending on the characteristics of the businesses before to the outbreak. To our knowledge, no study has been conducted on the connection between different firm-level variables and the stock price response to the COVID-19 pandemic in the Financial industry. We can better understand the relationship between company characteristics and stock market responses to 
the epidemic by thoroughly analysing these features. As a result, this research presents an unpleasant but important chance to acquire insight into the factors that drive restaurant company stock returns and the operation of equity markets during this unprecedented crisis in recent memory. In pursuit of fulfilling the purpose of this study, this paper tries to include the stock return and other financial characteristics data of banks, non-bank financial institutions and insurance companies listed in the Dhaka Stock Exchange (DSE) before and during the COVID-19 crisis.

The remainder of this study is organised as follows: Section-2 presents the related background literature, Section-3 describes the methodology used in this study, Section-4 explains the empirical findings and analysis, and Section-5 concludes the study's findings.

\section{Background Literature}

Since its outbreak, COVID-19 has not only caused unprecedented human and health crises but triggered financial distress globally. The global economic growth was projected at 3 percent in 2020, far worse than the outcome of the Global Financial Crisis in 2009. A substantial number of studies has been covered to investigate the impact of the COVID-19 crisis, particularly over the financial market and economy as a whole, while a few empirical works have been done to assess the impact on the global and regional banking sector (Colak \& Öztekin, 2020; Elnahass et al., 2021; Islam et al., 2020; Mersha \& Worku, 2020; Sutrisno et al., 2020) and on microfinance institutions (Zheng \& Zhang, 2021).

Elnahass et al. (2021) constructed a regression model for panel data of 1090 banks from 116 countries for quarterly periods on 2019-2020 to identify detrimental impacts of COVID-19 outbreak on financial performance over the global banking sector. It is evident from their study that banks have suffered from an immediate exogenous shock of COVID-19 in terms of various indicators covering the measures of financial performance and financial stability such as return on assets (ROA), return on equity (ROE), the cost to income ratio, Tobin Q ratio, market to book value, non-performing loan to loan measures and some other key indicators. In another study, Colak and Öztekin (2020) showed how commercial banks from the Eurozone were affected in profitability followed by lending activities due to an increase in non-performing loans. The study proposed to provide proper recovery plans by banking authorities, especially for small and medium-sized banks, to manage the post-pandemic situations.

Colak and Öztekin (2020) put insight into factors that amplify the effects of the COVID-19 pandemic by lending to better understand the heterogeneity of lending patterns. After investigating international data on banks from 125 countries under cross-country studies, they found a difference in lending behaviour in the current global pandemic (also known as the "black swan" event). Bank lending response to this common shock depends on financial reports' characteristics such as size, operating performance, bank market structure (local and foreign banks, government and private banks), etc. The study reveals that foreign banks choose a "flight home" approach to reduce foreign exposure where small banks, government-backed banks are more adversely influenced by the coronavirus pandemic. Similar to conventional banking, Islamic banks face challenges in liquidity and ratios of 
non-performing financing amid the pandemic (Sutrisno et al., 2020).

Besides, after examining the financial and social efficiency of microfinance institutions (MFIs) for eleven developing Asian countries, Zheng and Zhang (2021) found that COVID-induced economic damage influenced the performance of MFIs in providing financial support to poor and low-income households and small businesses who are excluded from mainstream financial services and heavily rely on MFIs. Their study identified the weakening effect of pandemics over the vulnerable borrowers as they might default on their repayments due to higher lending rates charged by such institutions. Islam et al. (2020) showed that South Asian countries' economic slowdown during the COVID-19 pandemic in 2020 resulted in unprecedented reversals in capital flow due to travel restrictions and trade, along with a significant decrease in remittance inflows. Mersha and Worku (2020) have revealed how COVID-19 brought difficulties in deposit mobilisation, credit management, international banking and system security in the Ethiopian banking industry.

Although the global financial system has suffered from the immediate exogenous shock induced by COVID-19, the banking sector was expected to play an important role in absorbing the shock by supplying credit to the households and corporate sector (Demirgüç-Kunt et al., 2020). Thus, banks play a central role in contributing to the foundations of economic recovery (Feyen et al., 2020). The policymakers should focus on getting banks to raise new equity capital, in some way referred to as dynamic resilience, not just to maintain their risk-based capital ratios but to recapitalise promptly following an adverse shock to the system (Blank et al., 2020).

However, there have been extensive studies examining the reactions of developing countries' financial sectors in response to the pandemic caused by COVID-19, empirical work in developing countries is relatively limited. This study contributes to the growing literature as the purpose of our study is to measure the banking industry's response of an emerging economy to macroeconomic shock due to the magnitude of COVID-19. Bangladesh's banking industry has been struggling with poor performance because of heavy mounting with non-performing loans (NPLs) and is crippled with other systematic problems before the COVID-19 situations. The pandemic has put further stress on this sector. Barua and Barua (2020) estimated the impact of COVID-19 induced economic downturn under different NPL shock scenarios for publicly listed commercial banks. The study findings showed that all banks are experiencing a fall in three dimensions; risk-weighted asset value, capital adequacy ratio and interest income. It is also estimated that larger banks are relatively more vulnerable, and the situation will worsen if NPL shocks become larger. Performing multiple-criteria-decision-making (MCDM) tools on eighteen publicly listed commercial banks of Bangladesh with an aim to analyse and forecast the financial stability and resilience of banks by categorising them into three groups; top resilient, moderate resilient and low resilient in response to the weakening effects of COVID-19 pandemic, Ghosh and Saima (2021) also conclude that banks with low capital adequacy, low liquidity ratio, low performance with higher NPLs were more vulnerable to the shocks of the pandemic. The study highlights that banks with higher loan concentration in the industrial sectors are negatively affected during this pandemic and can only be survived if they maintain a higher 
capital base and the highest short-term liquidity and lowest NPLs. Rahman et al. (2020) has identified a bank's liquidity crisis from March to November 2020 in their study focusing on the impact of COVID-19 on the bank's liquidity for twenty commercial banks. The study findings include government action variables (social distancing and economic support) that significantly affect banking liquidity while remittance played the role of key stabiliser. In addition, banks may also face a liquidity crisis when depositors choose to withdraw their savings to support their livings and health expenses (Begum et al., 2020).

\section{Research Methodology}

\subsection{Data}

The sample of this study consists of the listed financial institutions (Banks, NBFIs and Insurance companies) of the Dhaka Stock Exchange (DSE), the major stock exchange of Bangladesh. We collected the dividend-adjusted daily stock price data from Datastream. In addition, we collected firm financial characteristics data from annual reports. We dropped firms with unavailable data, and thus the observation of this study stands as $N=1050$. Since we used the weekly stock return as a proxy of financial performance, we designed the sample period from 11th March to 19th August (The first patient of COVID-19 in Bangladesh was identified at the beginning of March, and in August, the first wave of COVID-19 started to be decline noticeably), considering a week from Sunday to Thursday according to the trading calendar of DSE. Also, we excluded the period when the stock market remained closed since the stock trading was interrupted.

\subsection{Empirical Model and Method of Estimation}

To investigate the effect of COVID-19 on the financial industry's performance, considering the pre-pandemic characteristics, we propose the empirical model as follows:

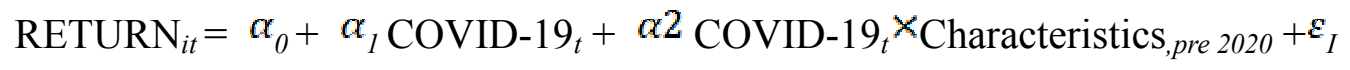

Where RETURN represents weekly stock returns (in percentage) of each firm. COVID-19 represents the growth of weekly confirmed cases in Bangladesh, COVID-19 $\times$ Characteristics $_{i}$ represents the interaction between the pre-pandemic firm financial characteristics and COVID-19 growth of confirmed cases in a week. In this equation, we have included error terms, time (week, year) and firm are represented by $t$ and i, respectively.

In addition to providing maximum likelihood estimates, we utilised the GEE technique, which has often been used in the strategic management literature, especially in cases when Panel data is used to evaluate organisational performance (Henderson et al., 2006; Hilbe \& Hardin, 2008; Song et al., 2021).

As a proxy of the financial industry's performance, the dependent variable of our study, we used stock return (weekly). After obtaining the data from Datastream, we calculated the stock return for the sample period (11th March to 19th August 2020). To avoid the biased stock return measure, we confirmed this variable's calculation with the dividend-adjusted closing price. To compute the weekly stock return, the closing price of week $t$ is subtracted from the 
price of week t-1 and then divided by the price of week t-1 (Ramelli \& Wagner, 2020).

To construct the variable COVID-19, the daily confirmed COVID-19 cases and deaths data was taken from the WHO website. COVID-19 growth rates were determined, and to align COVID-19 weekly growth rates with sampled Financial companies' weekly stock returns, we established a week from Saturday to Friday, comparable with stock market trading days. The following equation is used to determine the weekly growth rate of COVID-19 cases: COVID-19 $=\log (1+$ Number of confirmed cases in week $t)-\log (1+$ Number of confirmed cases in week t-1) (Ramelli \& Wagner, 2020).

We further used several variables as a proxy of pre-pandemic firm characteristics. In the context of the prior research indicating that company size affects a company's market concentration benefit, growth opportunities, and profitability, a firm's size (SIZE) was finally characterised using the log of total assets (Alabdullah et al., 2018; Orser et al., 2000; Pervan \& Višić, 2012; Samiee \& Walters, 1990). Following that, leverage was defined as a key financial situation indicating a firm's liquidity, as measured by the debt-to-equity ratio (Ibhagui \& Olokoyo, 2018; Tsuruta, 2015; Acharya \& Mora, 2015). Considering liquidity as a strong indicator of a firm's capacity to react to COVID-19, we included it in our equation. Liquidity was estimated as cash divided by total assets (Bates et al., 2009; Giroud \& Mueller, 2017). Finally, the past profitability of a firm was measured by ROA (net income divided by total assets) (Ding et al., 2021).

\section{Results}

\subsection{Descriptive Statistics}

Table 1. Descriptive statistics $(\mathrm{N}=1050)$

\begin{tabular}{lllllll}
\hline Variables & Mean & Std. Dev. & Min & Max & Skew. & Kurt. \\
\hline RETURN & .013 & .071 & -.273 & .382 & .821 & 7.318 \\
COV-19 (Cases) & .061 & .188 & -.184 & .412 & .612 & 2.01 \\
COV-19 (Deaths) & .107 & .278 & -.119 & 1 & 2.281 & 7.473 \\
SIZE & 10.097 & 2.313 & 6.711 & 13.948 & -.023 & 1.461 \\
LEV & .74 & .324 & .813 & 2.012 & .533 & 5.016 \\
LIQ & .188 & .187 & 0 & .79 & 1.071 & 3.256 \\
ROA & .06 & .05 & -.187 & .118 & -3.553 & 17.457 \\
\hline
\end{tabular}

The descriptive statistics for the variables in our study model are shown in Table 1. During the sample window of our study, the weekly stock return was $1.30 \%$ ranging from negative $-27.30 \%$ to $38.20 \%$. The confirmed cases' weekly growth was $6.10 \%$ on average, while the death's growth was $10.70 \%$. The mean company size is 10.01 , suggesting an average asset value of Taka. 86813.5 million for the companies. The ratio of total liabilities to total assets (Leverage) on an average basis is $74.0 \%$ ranging from $81.3 \%$ to $201.2 \%$. The average ROA 
was $6.0 \%$ ranging from negative $18.70 \%$ to $11.80 \%$.

Correlation coefficients for the variables included in the regression models are shown in Table 2 to see if there are any strongly connected variables. We discover that the correlation coefficients with the greatest absolute value are 0.71 for a negative connection between liquidity and company size (SIZE). To address the problem of multicollinearity in more detail, we examine the variance inflation factor (VIF) for each dependent variable. The VIF score for each variable, the mean, is less than the crucial value of 10 , indicating no multicollinearity indication (Gujarati, 2008).

Table 2. Pairwise Correlation Matrix

\begin{tabular}{|c|c|c|c|c|c|c|c|c|}
\hline Variables & RETURN & $\begin{array}{l}\text { COV19 } \\
\text { (Cases) }\end{array}$ & $\begin{array}{l}\text { COV19 } \\
\text { (Deaths) }\end{array}$ & SIZE & LEV & LIQ & ROA & VIF \\
\hline RETURN & 1.00 & & & & & & & \\
\hline COV-19 (Cases) & $-0.15 * * *$ & 1.00 & & & & & & 1 \\
\hline COV-19(Deaths) & $-0.39 * * *$ & $0.60 * * *$ & 1.00 & & & & & 1 \\
\hline SIZE & $-0.10 * * *$ & 0.00 & 0.00 & 1.00 & & & & 2.575 \\
\hline LEV & $-0.09 * * *$ & 0.00 & 0.00 & $0.68^{* * *}$ & 1.00 & & & 2.328 \\
\hline LIQ & $0.06^{*}$ & 0.00 & 0.00 & $-0.71 * * *$ & $-0.63 * * *$ & 1.00 & & 2.201 \\
\hline ROA & -0.01 & 0.00 & 0.00 & 0.04 & $-0.23 * * *$ & 0.00 & 1.00 & 1.152 \\
\hline
\end{tabular}

Note. ${ }^{* * *} \mathrm{p}<0.01,{ }^{* *} \mathrm{p}<0.05,{ }^{*} \mathrm{p}<0.1$.

\subsection{Regression Analysis}

Table 3 summarises the primary analysis conducted using GEE. Firstly, we examined the effect of COVID-19 on stock returns in the immediate pre-pandemic financial year 2019 using firm-specific financial characteristic factors (without interaction). Without interaction terms, the result indicates that COVID-19 has a negative effect on RETURNS in the first column. More precisely, a unit increase in COVID-19 leads to a -5.60 percent reduction in RETURN (p-value less than 0.01). When we examined the moderating impact of the four financial circumstances, we discovered that SIZE and LEV produce a moderate negative connection between COVID-19 and RETURN. This indicates that companies with more extensive debt were more likely to be impacted by stock return decreases in response to COVID-19.

In the second column, we observed a significant effect of COVID-19 with SIZE, LEV and ROA on RETURN. Although we used company characteristics as of 2019 to ensure the robustness of our primary findings, we also computed coefficients using values for the 2017-2019 three-year average of firm characteristics. SIZE, LEV, and ROA all had a positive moderating impact in columns 3 and 4, similar to the findings in column 2, but the coefficient values vary somewhat between the two estimates. 
Table 3. Regression analysis

\begin{tabular}{|c|c|c|c|c|}
\hline & \multicolumn{2}{|c|}{ Panel 1 (2019) } & \multicolumn{2}{|c|}{ Panel 2 (2017-2019) } \\
\hline & RETURN & RETURN & RETURN & RETURN \\
\hline \multirow[t]{2}{*}{ COV19 } & $-.056 * * *$ & $-.265 * * *$ & $-.056 * * *$ & $-.237^{* * *}$ \\
\hline & $(.012)$ & $(.077)$ & $(.012)$ & $(.067)$ \\
\hline \multirow[t]{2}{*}{ SIZE } & $-.003 * * *$ & $-.004 * * *$ & $-.003 * * *$ & $-.004 * * *$ \\
\hline & $(.001)$ & $(.001)$ & $(.001)$ & $(.001)$ \\
\hline \multirow[t]{2}{*}{ LEV } & $-.012 * *$ & $-.016^{* *}$ & $-.011 * *$ & $-.015^{* *}$ \\
\hline & $(.005)$ & $(.007)$ & $(.005)$ & $(.006)$ \\
\hline \multirow[t]{2}{*}{ LIQ } & -.014 & -.013 & -.01 & -.008 \\
\hline & $(.012)$ & $(.014)$ & $(.014)$ & $(.017)$ \\
\hline \multirow[t]{2}{*}{ ROA } & -.021 & -.001 & -.006 & .025 \\
\hline & $(.039)$ & $(.045)$ & $(.048)$ & $(.057)$ \\
\hline \multirow[t]{2}{*}{ SIZE*COV-19 } & & $.017 * * *$ & & $.017 * * *$ \\
\hline & & $(.006)$ & & $(.006)$ \\
\hline \multirow[t]{2}{*}{ LEV*COV-19 } & & $.073^{*}$ & & $.064^{*}$ \\
\hline & & $(.04)$ & & $(.038)$ \\
\hline \multirow[t]{2}{*}{ LIQ*COV-19 } & & -.008 & & -.033 \\
\hline & & $(.083)$ & & $(.085)$ \\
\hline \multirow[t]{3}{*}{$\mathrm{ROA} * \mathrm{COV}-19$} & & $-.33^{*}$ & & $-.498 *$ \\
\hline & & (.19) & & $(.277)$ \\
\hline & & & & $(.277)$ \\
\hline \multirow[t]{2}{*}{ _cons } & $.056^{* * *}$ & $.069 * * *$ & $.053^{* * *}$ & $.064 * * *$ \\
\hline & $(.013)$ & $(.015)$ & $(.012)$ & $(.013)$ \\
\hline Observations & 1050 & 1050 & 1050 & 1050 \\
\hline Wald Chi ${ }^{2}$ & 28.61 & 62.317 & 34.644 & 70.388 \\
\hline
\end{tabular}

Note. Robust standard errors are in parentheses; ${ }^{* * *} \mathrm{p}<.01,{ }^{* *} \mathrm{p}<.05,{ }^{*} \mathrm{p}<.1$.

\subsection{Sensitivity Analysis}

To further check the sensitivity of our empirical result, we used the alternative measure of our main dependent variable, COVID-19, measured as the weekly growth rates of deaths in Bangladesh (See Table 4). We found similar results presented in Table 3, affirming our empirical findings' validity and significance. 
Table 4. Sensitivity analysis

\begin{tabular}{|c|c|c|c|c|}
\hline & \multicolumn{2}{|c|}{ Panel 3 (2019) } & \multicolumn{2}{|c|}{ Panel 4 (2017-2019) } \\
\hline & RETURN & RETURN & RETURN & RETURN \\
\hline \multirow[t]{2}{*}{ COV-19 } & $-.101 * * *$ & $-.236 * * *$ & $-.101 * * *$ & $-.217 * * *$ \\
\hline & $(.01)$ & $(.052)$ & $(.01)$ & $(.066)$ \\
\hline \multirow[t]{2}{*}{ SIZE } & $-.003 * * *$ & $-.004 * * *$ & $-.003 * * *$ & $-.004 * * *$ \\
\hline & $(.001)$ & $(.001)$ & $(.001)$ & $(.001)$ \\
\hline \multirow[t]{2}{*}{ LEV } & $-.012 * *$ & $-.02 * * *$ & $-.011 * *$ & $-.019 * * *$ \\
\hline & $(.005)$ & $(.007)$ & $(.005)$ & $(.007)$ \\
\hline \multirow[t]{2}{*}{ LIQ } & -.014 & -.014 & -.01 & -.008 \\
\hline & $(.012)$ & $(.016)$ & $(.014)$ & $(.019)$ \\
\hline \multirow[t]{2}{*}{ ROA } & -.021 & .032 & -.006 & .044 \\
\hline & $(.039)$ & $(.029)$ & $(.048)$ & $(.045)$ \\
\hline \multirow[t]{2}{*}{ SIZE*COV-19 } & & $.01 * *$ & & $.01 * *$ \\
\hline & & $(.004)$ & & $(.005)$ \\
\hline \multirow[t]{2}{*}{ LEV*COV-19 } & & $.08^{* *}$ & & $.066^{*}$ \\
\hline & & $(.036)$ & & $(.034)$ \\
\hline \multirow[t]{2}{*}{ LIQ*COV-19 } & & .004 & & -.022 \\
\hline & & $(.066)$ & & $(.074)$ \\
\hline \multirow[t]{2}{*}{$\mathrm{ROA} * \mathrm{COV}-19$} & & $-.498 *$ & & -.464 \\
\hline & & $(.295)$ & & $(.324)$ \\
\hline \multirow[t]{2}{*}{ _cons } & $.063^{* * *}$ & $.078 * * *$ & $.06^{* * *}$ & $.073 * * *$ \\
\hline & $(.013)$ & $(.014)$ & $(.012)$ & $(.014)$ \\
\hline Observations & 1050 & 1050 & 1050 & 1050 \\
\hline Wald $\mathrm{Chi}^{2}$ & 127.2 & 314.338 & 118.032 & 324.349 \\
\hline
\end{tabular}

Note. Robust standard errors are in parentheses; $* * * \mathrm{p}<.01,{ }^{* *} \mathrm{p}<.05,{ }^{*} \mathrm{p}<.1$.

\section{Conclusion}

Financial institutions nationally and internationally are observing and responding to the COVID-19 pandemic's consequences. In relation to financial circumstances, this research revealed that company size and leverage negatively influence the association between COVID-19 and stock returns, which is consistent with the previous results from different industry samples (Ding et al., 2021). These findings indicate that companies with bigger size and higher leverage, on average, seem to be more likely to sustain during the challenging time more successfully by financing themselves, resulting in fair market value for investors when compared to otherwise comparable firms (Ramelli \& Wagner, 2020). To our knowledge, this is the first investigation of its kind, the shock of COVID-19 on the financial sector, one of the most affected industries of Bangladesh. Thus, the findings of this research should add 
to the financial literature by elucidating the financial implications of COVID-19. Additionally, owners and senior managers of financial companies may use the findings of this research to create financial plans geared toward becoming or remaining robust to stock market declines in the aftermath of an unanticipated catastrophe such as the COVID-19 shock.

This research has limitations. Firstly, since this research examined the moderating impact of pre-pandemic features on the effect of COVID-19 shock on stock returns using a sample of Bangladesh's publicly listed financial companies, its findings cannot be extended to other nations or industries settings. Secondly, according to data availability and our primary interest in changes in stock response to COVID-19, this research excluded non-publicly listed financial companies. The effect can be analysed for future studies considering the multiple waves, industries, and regional context.

\section{References}

Acharya, V. V., \& Mora, N. (2015). A crisis of banks as liquidity providers. The Journal of Finance, 70(1), 1-43. https://doi.org/10.1111/jofi.12182

Alabdullah, T. T. Y., Ahmed, E. R., \& Yahya, S. (2018). The determination of firm performance in emerging nations: Do board size and firm size matter? International Academic Journal of Accounting and Financial Management, 5(2), 57-66. https://doi.org/10.9756/IAJAFM/V5I2/1810017

Andersen, A. L., Hansen, E. T., Johannesen, N., \& Sheridan, A. (2020). Consumer Responses to the COVID-19 Crisis: Evidence from Bank Account Transaction Data (SSRN Scholarly Paper ID 3609814). Social Science Research Network. https://doi.org/10.2139/ssrn.3609814

Bates, T. W., Kahle, K. M., \& Stulz, R. M. (2009). Why do US firms hold so much more cash than they used to? The Journal of Finance, 64(5), 1985-2021. https://doi.org/10.1111/j.1540-6261.2009.01492.x

Begum, M., Farid, M. S., Alam, M. J., \& Barua, S. (2020). COVID-19 and Bangladesh: Socio-economic analysis towards the future correspondence. Asian Journal of Agricultural Extension, Economics \& Sociology, 143-155. https://doi.org/10.9734/ajaees/2020/v38i930417

Blank, M., Hanson, S., Stein, J., \& Sunderam, A. (2020). How should US bank regulators respond to the Covid-19 crisis (p. 63)? Hutchins Center on Fiscal and Monetary Policy at Brookings, Hutchins Center Working Paper.

Colak, G., \& Öztekin, Ö. (2020). The Impact of COVID-19 Pandemic on Bank Lending Around the World. Journal of Banking and Finance, Forthcoming. https://doi.org/10.2139/ssrn.3712668

Demirgüç-Kunt, A., Pedraza, A., \& Ruiz Ortega, C. (2020). Banking Sector Performance During the COVID-19 Crisis (SSRN Scholarly Paper ID 3689789). Social Science Research Network. https://doi.org/10.2139/ssrn.3689789

Didier, T., Huneeus, F., Larrain, M., \& Schmukler, S. L. (2021). Financing firms in 
hibernation during the COVID-19 pandemic. Journal of Financial Stability, 53, 100837. https://doi.org/10.1016/j.jfs.2020.100837

Ding, W., Levine, R., Lin, C., \& Xie, W. (2021). Corporate immunity to the COVID-19 pandemic. Journal of Financial Economics, 141(2), 802-830. https://doi.org/10.1016/j.jfineco.2021.03.005

Elnahass, M., Trinh, V. Q., \& Li, T. (2021). Global banking stability in the shadow of Covid-19 outbreak. Journal of International Financial Markets, Institutions and Money, 72, 101322. https://doi.org/10.1016/j.intfin.2021.101322

Faria-e-Castro, M. (2021). Fiscal policy during a pandemic. Journal of Economic Dynamics and Control, 125, 104088. https://doi.org/10.1016/j.jedc.2021.104088

Feyen, E., Alonso Gispert, T., Kliatskova, T., \& Mare, D. S. (2020). Taking Stock of the Financial Sector Policy Response to COVID-19 around the World. The World Bank. https://doi.org/10.1596/1813-9450-9497

Ghosh, R., \& Saima, F. N. (2021). Resilience of commercial banks of Bangladesh to the shocks caused by COVID-19 pandemic: An application of MCDM-based approaches. Asian Journal of Accounting Research. https://doi.org/10.1108/AJAR-10-2020-0102

Giroud, X., \& Mueller, H. M. (2017). Firm leverage, consumer demand, and employment losses during the great recession. The Quarterly Journal of Economics, 132(1), 271-316. https://doi.org/10.1093/qje/qjw035

Gujarati, D. (2008). Basic econometrics (pp. 363-369). New York: MeGraw-Hill.

Henderson, A. D., Miller, D., \& Hambrick, D. C. (2006). How quickly do CEOs become obsolete? Industry dynamism, CEO tenure, and company performance. Strategic Management Journal, 27(5), 447-460. https://doi.org/10.1002/smj.524

Hilbe, J. M., \& Hardin, J. W. (2008). Generalised estimating equations for longitudinal panel analysis. Handbook of Longitudinal Research: Design, Measurement, and Analysis, 1, 467-474.

Ibhagui, O. W., \& Olokoyo, F. O. (2018). Leverage and firm performance: New evidence on the role of firm size. The North American Journal of Economics and Finance, 45, 57-82. https://doi.org/10.1016/j.najef.2018.02.002

Islam, M. M., Jannat, A., Al Rafi, D. A., \& Aruga, K. (2020). Potential Economic Impacts of the COVID-19 Pandemic on South Asian Economies: A Review. World, 1(3), 283-299. https://doi.org/10.3390/world1030020

Kocaarslan, B., \& Soytas, U. (2021). The Asymmetric Impact of Funding Liquidity Risk on the Volatility of Stock Portfolios during the COVID-19 Crisis. Sustainability, 13(4), 2286. https://doi.org/10.3390/su13042286

Mersha, D., \& Worku, A. (2020). Effect of COVID-19 on the Banking Sector in Ethiopia. Horn of African Journal of Business and Economics (HAJBE), 28-38. 


\section{Macrothink}

Business and Management Horizons

ISSN 2326-0297

Orser, B. J., Hogarth-Scott, S., \& Riding, A. L. (2000). Performance, firm size, and management problem solving. Journal of Small Business Management, 38(4), 42.

Pervan, M., \& Višić, J. (2012). Influence of firm size on its business success. Croatian Operational Research Review, 3(1), 213-223.

Rahman, M. M., Zaman, R., \& Begum, M. (2020). Bank Liquidity during COVID-19 Pandemic: Evidence from Bangladesh (SSRN Scholarly Paper ID 3778056). Social Science Research Network. https://doi.org/10.2139/ssrn.3778056

Ramelli, S., \& Wagner, A. F. (2020). Feverish stock price reactions to COVID-19. The Review of Corporate Finance Studies, 9(3), 622-655. https://doi.org/10.1093/rcfs/cfaa012

Samiee, S., \& Walters, P. G. (1990). Influence of firm size on export planning and performance. Journal of Business Research, 20(3), 235-248. https://doi.org/10.1016/0148-2963(90)90015-6

Song, H. J., Yeon, J., \& Lee, S. (2021). Impact of the COVID-19 pandemic: Evidence from the U.S. restaurant industry. International Journal of Hospitality Management, 92, 102702. https://doi.org/10.1016/j.ijhm.2020.102702

Sutrisno, S., Panuntun, B., \& Adristi, F. I. (2020). The Effect of Covid-19 Pandemic on the Performance of Islamic Bank in Indonesia. EQUITY, 23(2), 125-136. https://doi.org/10.34209/equ.v23i2.2245

Tsuruta, D. (2015). Leverage and firm performance of small businesses: Evidence from Japan. Small Business Economics, 44(2), 385-410. https://doi.org/10.1007/s11187-014-9601-5

Zaremba, A., Kizys, R., Tzouvanas, P., Aharon, D. Y., \& Demir, E. (2021). The quest for multidimensional financial immunity to the COVID-19 pandemic: Evidence from international stock markets. Journal of International Financial Markets, Institutions and Money, 101284. https://doi.org/10.1016/j.intfin.2021.101284

Zheng, C., \& Zhang, J. (2021). The impact of COVID-19 on the efficiency of microfinance institutions. International Review of Economics \& Finance, 71, 407-423. https://doi.org/10.1016/j.iref.2020.09.016

\section{Copyrights}

Copyright for this article is retained by the author(s), with first publication rights granted to the journal.

This is an open-access article distributed under the terms and conditions of the Creative Commons Attribution license (http://creativecommons.org/licenses/by/4.0/). 